\title{
Assessment of quality and safety indicators of beverages made from vegetable raw materials
}

\author{
Anna I. Belousova* and Lyudmila V. Donchenko \\ Kuban State Agrarian University named after I.T.Trubilin, Krasnodar, Russia
}

\begin{abstract}
Organoleptic and physical and chemical parameters of new pectin-containing beverages based on vegetable juices are given. Their compliance with the requirements of the technical regulations of the Customs Union in terms of safety indicators was confirmed. The conclusion about the feasibility of setting up new types of beverages for production was made.
\end{abstract}

Nutrition is one of the most important factors that determines a person's health. Most of the products consumed are of natural origin: animal or vegetable, in some cases mineral. Ensuring the safety of food raw materials and food products is one of the most important tasks of modern society, which determines the health of the nation [1].

Food quality is a set of properties that reflect the ability of a product to provide the human body with vital substances, meet state standards, be safe for the consumer, reliable in terms of the stability of the composition and preservation of consumer properties of the product [2].

The quality of food products is characterized by organoleptic and chemical indicators (color, taste, smell, consistency, appearance, chemical composition), the absence of toxins, pathogenic microbes, harmful compounds and foreign impurities.

Pectin in a hydrated form was used as an added preventive component when developing vegetable drinks for specialized purposes (Fig.1).

\footnotetext{
* Corresponding author: anna-lepshina93@mail.ru
} 


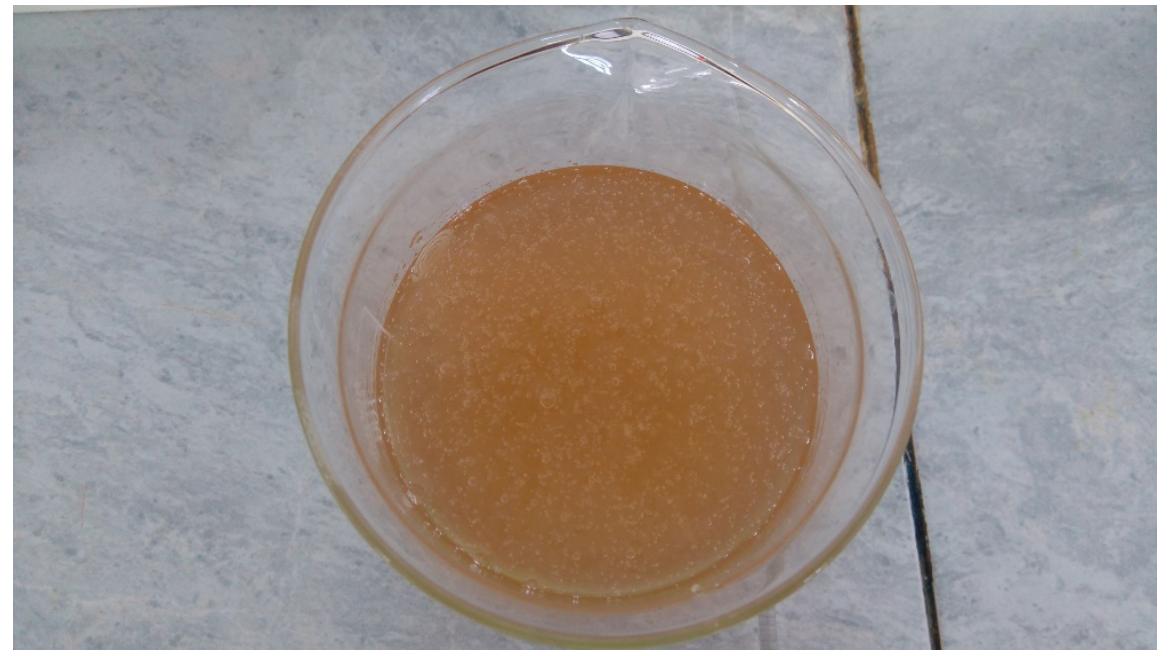

Fig. 1. Hydratopectin.

Pectin is called the "keeper" of our body, because it has the ability to adsorb harmful substances on its surface: heavy metals and radioactive elements, while not disturbing the natural bacteriological balance of the body. It also helps to enhance the taste, allows you to get a more uniform product, preventing the settling of the pulp, supports the natural flavor, provides a taste perception of the juice [3]. Drinks are developed on the basis of tomato juice with the addition of cucumber juice, sweet pepper puree, beetroot pectin extract, salt, sugar, black pepper extract and bay leaf (Fig. 2).

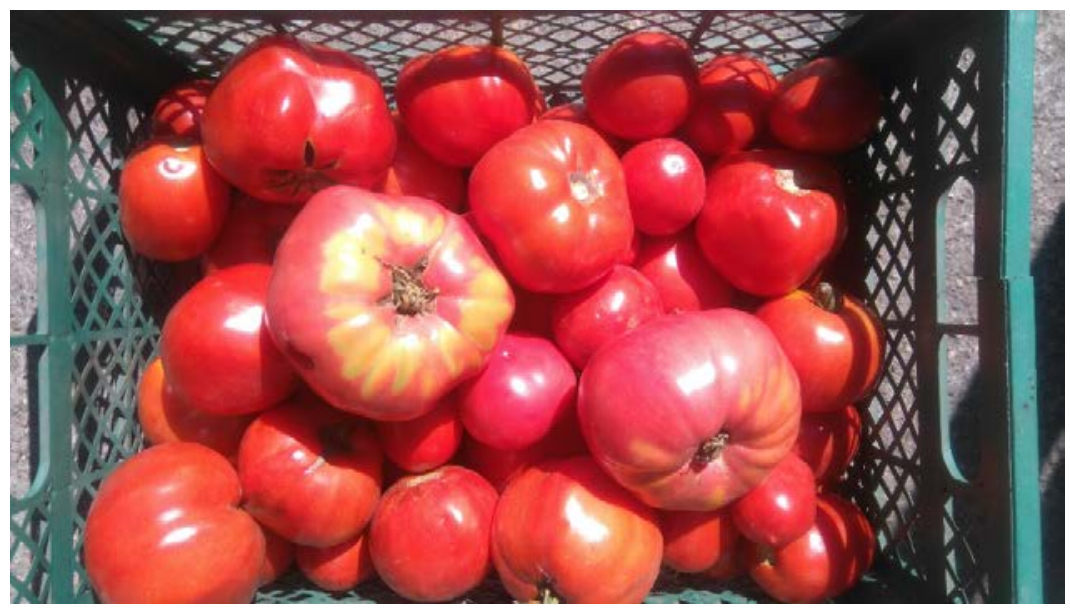

Fig. 2. Tomatoes - main raw material for developed beverage.

To implement the developed vegetable drinks for production, the product quality was evaluated [4]. Drinks "Lightness" and "Spice" have the following organoleptic and physicochemical indicators, which are presented in tables 1 and 2.

Table 1. Organoleptic indicators.

\begin{tabular}{|l|l|}
\hline Title of the indicator & \multicolumn{1}{|c|}{ Characteristics of drinks } \\
\hline Appearance and consistency & \multicolumn{1}{|c|}{ Homogeneous opaque liquid } \\
\hline Colour & $\begin{array}{c}\text { Homogeneous throughout the whole mass, it } \\
\text { corresponds to the applied juices }\end{array}$ \\
\hline
\end{tabular}


Table 2. Physico-chemical indicators.

\begin{tabular}{|c|c|c|}
\hline \multirow{2}{*}{ Indicators } & \multicolumn{2}{|c|}{ Content in the samples } \\
\hline & «Lightness» & «Spice» \\
\hline Mass fraction of dry substances, \% & 8,15 & 8,2 \\
\hline Titratable acidity, \% & 2,8 & 2,7 \\
\hline Pectin, \% & 0,95 & 0,9 \\
\hline
\end{tabular}

Based on the data obtained from the research of quality indicators, we have developed a project of Technical Specifications, TI and RC.

Potentially dangerous to human health, biological, chemical, toxic and radioactive substances enter products and accumulate there, passing through the food chain, which includes all stages of agricultural production: storage, transportation, preparation of products and auxiliary materials, technological operations, packaging and packaging of finished products $[5,6]$.

In accordance with the "Technical Regulations for juice products from fruits and vegetables" 023/2011, Tables 3 and 4 show the safety requirements to vegetable beverages.

Table 3. Microbiological indicators of the beverage «Lightness».

\begin{tabular}{|c|c|c|c|}
\hline \multicolumn{2}{|c|}{ Title of the indicator } & PS RC & According to the \\
\hline \multicolumn{2}{|l|}{ KMAFAnM, KOE/(m³ ${ }^{3}$, no more } & $5 * 10^{3}$ & $1,1 * 10^{2}$ \\
\hline $\begin{array}{l}\text { Mass of the product }\left(1 \mathrm{~cm}^{3}\right) \text {, in } \\
\text { which it is not allowed }\end{array}$ & BGKP (coliforms) & not allowed & not detected \\
\hline \multicolumn{2}{|l|}{ Yeast, COE $/ \mathrm{cm}^{3}$, no more } & $2 * 10^{3}$ & $<10$ \\
\hline \multicolumn{2}{|l|}{ Molds, $\mathrm{COE} / \mathrm{cm}^{3}$, no more } & $5 * 10^{2}$ & $<10$ \\
\hline
\end{tabular}

Table 4. Microbiological indicators of the beverage «Spice».

\begin{tabular}{|c|c|c|c|}
\hline \multicolumn{2}{|c|}{ Title of the indicator } & TS TC & $\begin{array}{l}\text { According to the } \\
\text { regulation of tests }\end{array}$ \\
\hline \multicolumn{2}{|l|}{ KMAFAnM, KOE/cm³ ${ }^{3}$, no more } & $5 * 10^{3}$ & $1,5 * 10^{2}$ \\
\hline $\begin{array}{l}\text { Mass of the product }\left(1 \mathrm{~cm}^{3}\right) \text {, in } \\
\text { which it is not allowed }\end{array}$ & BGKP (coliforms) & not allowed & not detected \\
\hline \multicolumn{2}{|l|}{ Yeast, COE $/ \mathrm{cm}^{3}$, no more } & $2 * 10^{3}$ & $<10$ \\
\hline \multicolumn{2}{|l|}{ Molds, $\mathrm{COE} / \mathrm{cm}^{3}$, no more } & $5 * 10^{2}$ & $<10$ \\
\hline
\end{tabular}

In accordance with the technical regulation of the customs Union "On food safety" 021/2011, tables 5 and 6 show the safety requirements to vegetable beverages.

Table 5. Indicators of the safety of the beverage «Lightness».

\begin{tabular}{|l|l|c|c|}
\hline $\begin{array}{c}\text { Product } \\
\text { group }\end{array}$ & \multicolumn{1}{|c|}{ Indicators } & $\begin{array}{c}\text { Admissible } \\
\text { levels, } \mathrm{mg} / \mathrm{dm}^{3}, \\
\text { no more }\end{array}$ & $\begin{array}{c}\text { According to } \\
\text { the } \\
\text { regulation of } \\
\text { tests }\end{array}$ \\
\hline \multirow{4}{*}{$\begin{array}{l}\text { Vegetable } \\
\text { juices }\end{array}$} & Arsenic $\mathrm{mg} / \mathrm{kg}$ & 0,2 & $<0,001$ \\
\cline { 2 - 4 } & Cadmium $\mathrm{mg} / \mathrm{kg}$ & 0,03 & $0,01 \pm 0,001$ \\
\cline { 2 - 4 } & Mercury $\mathrm{mg} / \mathrm{kg}$ & 0,02 & $<0,002$ \\
\cline { 2 - 4 } & Lead $\mathrm{mg} / \mathrm{kg}$ & 0,5 & $0,05 \pm 0,001$ \\
\cline { 2 - 4 } & Mycotoxins: patulin, $\mathrm{mg} / \mathrm{cm}^{3}$ & 0,005 & $<0,003$ \\
\cline { 2 - 4 } & Nitrates, $\mathrm{mg} / \mathrm{dm}^{3}$ & 150 & $<36$ \\
\cline { 2 - 4 } & Alfa, beta, gamma - isomers & 0,5 & $<0,001$ \\
\cline { 2 - 4 } & DDT and its metabolites & 0,1 & $<0,005$ \\
\hline
\end{tabular}


Table 6. Indicators of the safety of the beverage «Spice».

\begin{tabular}{|c|l|c|c|}
\hline \multirow{2}{*}{$\begin{array}{c}\text { Product } \\
\text { group }\end{array}$} & \multicolumn{1}{|c|}{ Indicators } & $\begin{array}{c}\text { Admissible } \\
\text { levels, } \mathrm{mg} / \mathrm{dm}^{3}, \\
\text { no more }\end{array}$ & $\begin{array}{c}\text { According to } \\
\text { the } \\
\text { regulation of } \\
\text { tests }\end{array}$ \\
\hline \multirow{2}{*}{$\begin{array}{c}\text { Vegetable } \\
\text { juices }\end{array}$} & Arsenic $\mathrm{mg} / \mathrm{kg}$ & 0,2 & $<0,001$ \\
\cline { 2 - 4 } & Cadmium $\mathrm{mg} / \mathrm{kg}$ & 0,03 & $<0,01$ \\
\cline { 2 - 4 } & Mercury $\mathrm{mg} / \mathrm{kg}$ & 0,02 & $<0,002$ \\
\cline { 2 - 4 } & Lead $\mathrm{mg} / \mathrm{kg}$ & 0,5 & $0,08 \pm 0,002$ \\
\cline { 2 - 4 } & Mycotoxins: patulin, $\mathrm{mg} / \mathrm{cm}^{3}$ & 0,005 & $<0,003$ \\
\cline { 2 - 4 } & Nitrates, $\mathrm{mg} / \mathrm{dm}^{3}$ & 150 & $<36$ \\
\cline { 2 - 4 } & Alfa, beta, gamma - isomers & 0,5 & $<0,001$ \\
\cline { 2 - 4 } & DDT and its metabolites & 0,1 & $<0,005$ \\
\hline
\end{tabular}

The research was conducted in the research Institute "Biotechnology and food certification", (testing laboratory "Center of food quality", Center of collective use of scientific equipment of KubSAU) [1],[2],[7].

From the research conducted, it can be concluded that the safety indicators of vegetable drinks meet all the requirements of TS TC 023/2011 and TR TC 021/2011. Vegetable drinks "Lightness" and "Spice", taking into account their daily consumption in the amount of $200 \mathrm{ml}$, are recommended as a functional source of pectin. Projects of technical and technological documentation have been developed for the production of beverages.

\section{References}

1. Sobol I.V. Peculiarities of analytical characteristics of extracted pectin from sunflower /I.V. Sobol, L.V. Donchenko, L.Y. Rodionova, A.G. Koshchaev, A.V.Stepovoy // Asian Journal of Pharmaceutics, 2017. T. 11, № 1. - P. 97-100.

2. Ogneva O.A. Pectin-containing beverage with probiotic substances / O.A. Ogneva, L.V. Donchenko // Multidisciplinary network electronic scientific journal of Kuban State Agrarian University, 2015, № 107. - P. 333-341.

3. Degtyarev L.S. Properties and structure of galacturonic acid in pectin production technology. Proceedings of higher educational institutions. / L.S. Degtyarev, M.P. Kupchik, L.V. Donchenko, O.V.Bogdanova // Food Technology, 2002, № 4. - P. 15-17.

4. Il'ina I.A. Peculiarities of technology of highly prolonged pectines obtaining / I.A. Il'ina, L.V. Donchenko, Z.G. Zemskova // Herald of the Russian Agricultural Academy, 2003, № 3. - P. 8-10.

5. Azimova S.T. Towards food security through application of new scientific findings / S.T. Azimova, M.Z. Kizatova, S.O. Akhmetova, L.V. Donchenko, A.M.Admayeva // Journal of Security and Sustainability Issues, 2017. V. 6, № 4. - P. 719-728.

6. Belousova A. I. Innovation solutions in development of biocomponent beverage technology for specialized nutrition [Text] / A.I. Belousova, L.V. Donchenko // In the book: Food technologies: researches, innovations: materials of the $1^{\text {st }}$ national scientificresearch conference, Kerch, 2018: RGMTU, IMBI, AzSRIF, 2018. P. 6-8.

7. Donchenko L.V. Pectin: main properties, production and application / L.V. Donchenko, G.G. Firsov. M.: DeLi print, 2007. - 276 p. 